\title{
SIDE EFFECTS OF INTRAVENOUS PATIENT-CONTROLLED ANALGESIA WITH REMIFENTANIL COMPARED WITH INTERMITTENT EPIDURAL BOLUS FOR LABOUR ANALGESIA - A RANDOMIZED CONTROLLED TRIAL
}

\author{
Dafina Karadjova ${ }^{1}$, Mirjana Shosholcheva ${ }^{2}$, Emilija Ivanov ${ }^{1}$, Atanas Sivevski ${ }^{1}$, Ivo Kjaev ${ }^{1}$, \\ Adrijan Kartalov ${ }^{3}$, Biljana Kuzmanovska ${ }^{3}$, Rosa Spasova ${ }^{1}$, Goran Kocovski ${ }^{1}$, Irena Aleksiovska-Papestiev ${ }^{1}$ \\ ${ }^{1}$ University Clinic for Gynaecology and Obstetrics, Skopje, North Macedonia \\ ${ }^{2}$ University Clinic for surgical diseases "St. Naum Ohridski“, Skopje, North Macedonia \\ ${ }^{3}$ University Clinic for TOARILUC, Skopje, North Macedonia
}

Corresponding author: Dafina Karadjova, University Clinic for Gynaecology and Obstetrics, Skopje, North Macedonia, e-mail: dafinakaradzova@yahoo.com

\section{ABSTRACT}

Introduction: Epidural analgesia is considered a gold standard in obstetric anaesthesia and analgesia. However, in situation when it is contraindicated, unwanted by the patient or simply unavailable, remifentanil can be an excellent alternative. The goal of our study is to analyse the side effects of intravenous patient-controlled analgesia (IV PCA) with remifentanil compared with epidural analgesia during delivery. Material and methods: This study included 155 pregnant women in term for birth, divided into 2 groups: a remifentanil group (RG), and an epidural group (EG). Patients in the RG received intravenous PCA with remifentanil, while patients in the EG received epidural analgesia with programmed intermittent bolus dosing. Our primary outcome was maternal safety; the secondary outcome was neonatal safety.

Results: The results present a significantly lower $\mathrm{SaO} 2$ value of the parturients in the RG (96.95 \pm 1.4 vs $98.22 \pm 0.6$ ), and a significantly higher respiratory rate per minute in the EG at all time points after the onset of analgesia $(20.85 \pm 1.4$ vs $18.67 \pm 0.9)$. There was more frequent sedation, nausea and vomiting in the $\mathrm{RG}$, while in the EG there was a more elevated temperature, itching and irregularities in the CTG record. Regarding the newborn, there was no significant difference between the two groups in the Apgar scores, $\mathrm{pH}$, pCO2, pO2, and bicarbonate, while there was a significantly lower value of the base excess in the RG group. Conclusion: PCA with remifentanil is safe for the mother, foetus and the newborn, with minimal side effects. Continuous respiratory monitoring, oxygen supply and following of all consensus recommendations are mandatory.

Keywords: remifentanil, epidural analgesia, side effects

\section{INTRODUCTION}

Birth is one of the vital aspects of human existence and the birth pain is probably the strongest pain that any woman will experience in her lifetime.

Neuroaxial analgesia is the most effective method for pain relief in labour, while epidural analgesia is considered a gold standard in obstetric anaesthesia. [1] But there are conditions that limit the use of epidural analgesia: [2] when it is contraindicated, when there are some technical difficulties, or simply when it is not wanted from the parturient, because it is an invasive procedure and the side effects, although rare, can be very serious. An effective and safe alternative should be established. 
Remifentanil with its pharmacokinetic capacities can be ideal medicine for labour analgesia. It is an ultra-short acting, $\mu-1$ opioid receptor agonist, metabolized to an inactive metabolite by plasma and tissue esterases. It is characterized with a fast onset of analgesia, an analgesic half-life of 3.5-6 minutes and without an accumulation effect after its longterm use. [3] Plasma concentrations of remifentanil in pregnant women are approximately half of those found in women not pregnant. It crosses the placenta very quickly, but it is rapidly metabolized and redistributed in the foetus. [4]

In the last few years many studies have been discussing and debating the respiratory side effects associated with remifentanil analgesia. The goal of our study is to analyse the side effects of intravenous patient-controlled analgesia (IV PCA) with remifentanil compared with epidural analgesia.

\section{MATERIAL AND METHODS}

This is a prospective, randomized clinical study performed in the period from January 2016 to June 2017. The study was approved by the Ethic Committee for Human Research on 09.12.2015. Inclusion criteria for the study were: primiparous, patients older than 18 years of age, healthy or with a mild systemic disease (ASA 1 or 2), singleton pregnancy, vertex presentation and at term for birth (gestational age $>36$ weeks). Exclusion criteria were: complicated pregnancy, body weight $>120 \mathrm{~kg}$, contraindication for epidural analgesia and medical indication for epidural analgesia. All patients signed an informed consent before entering the study. The randomization took place after the patients were admitted in the hospital; there was not blindness and patients knew exactly in which group they were randomized. Patients were randomized into two groups: remifentanil intravenous analgesia group, and epidural analgesia group. Parturients in both groups, before the start of the analgesia, were prepared by placing a peripheral venous line and basic monitoring (non-invasive blood pressure, pulse oximetry, respiratory rate). We began with pain relief at $4-5 \mathrm{~cm}$ cervical dilatation, always in agreement with the attending obstetrician.

Patients in the remifentanil group (RG) received intravenous remifentanil in bolus doses on a pump for patient-controlled analgesia (PCA) with 2 minutes locked interval. We started the remifentanil analgesia with smaller doses and increased them gradually. We started with $0,2 \mu \mathrm{g} / \mathrm{kg}$ remifentanil (solution $20 \mu \mathrm{g} / \mathrm{ml}$ ), gradually increased for $0.1 \mu \mathrm{g} /$ $\mathrm{kg}$ up to the maximum bolus dose of $1 \mu \mathrm{g} / \mathrm{kg}$. All patients were explained how to operate the pump and when to give the bolus dose. We advised all the patients to apply the bolus when they felt that there was pain coming. A few labour pains were enough and the patients knew when to give the bolus. Analgesia was stopped ten minutes before the expected expulsion of the newborn. The whole time during the analgesia with remifentanil, the anaesthesiologist or experienced nurse remained in the delivery box with the labouring parturient.

Patients distributed in the epidural group (EG) received epidural analgesia with programmed intermittent bolus dosing. After the placement of the epidural catheter on level L2 - L3 or level L3 - L4 and a negative test dose ( $3 \mathrm{ml} 0.25 \%$ Bupivacain), all patients received a bolus dose of $10 \mathrm{ml} 0.1 \%$ Bupivacain with Fentanil $0.05 \mathrm{mg}$. Further on, all patients received an epidural bolus of $10 \mathrm{ml} 0.0625 \%$ Bupivacain with Fentanil $2 \mu \mathrm{g} / \mathrm{ml}$ every 60 minutes, starting 60 minutes after the initial dose. If needed, extra boluses of $5 \mathrm{ml} 0.1 \%$ Bupivacain were given for the treatment of breakthrough pain. Patients received the last bolus dose at least 30 minutes before the expected completion of the birth.

At all times during labour analgesia, the parturients were monitored: oxygen saturation and heart rate continuously; respiratory rate and non-invasive blood pressure every 15 minutes. The level of sedation was evaluated every 30 minutes by the Ramsey sedation score - RSS- (1- alert, anxious or restless; 2cooperative, oriented; 3 - responding to commands; 4- brisk response to stimuli; 5- weak and slow response to stimuli; 6- does not respond to strong painful stimuli). The incidence of nausea, vomiting, itching and hyperthermia was also recorded.

If oxygen saturation of the mother fell $<95 \%$, a nasal catheter with $\mathrm{O} 22-3 \mathrm{1} / \mathrm{min}$ was immediately placed, while if the mother's $\mathrm{SaO} 2$ fell $<92 \%$, or the respiratory rate (RR) decreased $<9$ or RSS was 4 or greater than 4, then we temporarily stopped with analgesia. After the normalization of the physiological parameters, the analgesia was started again with one step lower doses.

For neonatal safety, the foetal heart rate (FHR) was monitored with continuous cardiotocograph recording. If the FHR recordings became pathological (fetal bradycardia, late decelerations), we temporarily stopped with remifentanil analgesia. After the delivery, Apgar scores at the 1st, 5th and 10th minute were determined by the neonatologist. Any neonatal interventions in the immediate postnatal period were recorded. Blood 
from the umbilical artery (UA) was taken immediately after delivery and the acid-base status (ph, pCO2, pO2, bicarbonate and base excess) was measured.

During labour, both of the groups of patients were asked to answer two separate questions, to determine the level of pain and to determine the patient satisfaction with analgesia on specially designed scales for pain and satisfaction (visual analogue scale - VAS) from 0 (no pain/extremely dissatisfied) to 100 (highest possible pain/very satisfied).

For the statistical processing of the data obtained during the research, a database was created in the statistical program SPSS 17.0. For comparison of the analysed variables between the two groups independent tests ( $\mathrm{t}$-test for independent samples, Mann-Whitney U test, Chi-square Pearson test, Fisher exact test) were used, while to compare maternal and neonatal parameters in the remifentanil group, depending on the distribution of data, tests for dependent samples (McNemar tets, t-test for dependent samples, Friedman ANOVA test) were used.

\section{RESULTS}

155 patients were randomized to receive either PCA with remifentanil (80 patients) or intermittent epidural analgesia ( 75 patients) for painless delivery. Patient characteristics are given in Table 1.

Table 2 shows the average $\mathrm{SpO} 2$ and the mean RR in different time points in patients in both groups. The results present a significantly lower $\mathrm{SpO} 2$ in the remifentanil group and significantly more respirations per minute in the epidural analgesic group $(\mathrm{p}<0.0001)$ at all time points after the start of analgesia.

A nasal catheter with $\mathrm{O} 22-3 \mathrm{l} / \mathrm{min}$ was set only if SpO2 fell less than $95 \%$. 42 patients $(52.5 \%)$ from the remifentanil group needed $\mathrm{O} 2$ support, while only 2 patients $(2.67 \%)$ from the epidural group needed $\mathrm{O} 2(\mathrm{p}<0.0001)$. On average, patients in the remifentanil group received oxygen for 78 minutes. Only 1 patient in RG had a drop in saturation less than $92 \%$. The remifentanil analgesia was stopped, and after 5 minutes, the analgesia was continued with 1 step lower dose.

In the RG, we analysed the relationship between the dose of remifentanil and oxygen saturation using Pearson's correlation coefficient, and we found that these two parameters correlated negatively with each other, which means that the increase in the dose of remifentanil reduces oxygen saturation. But statistically this correlation was not significant, $\mathrm{R}=-0.0575, \mathrm{P}=0.61$.

The mean values of systolic blood pressure, diastolic blood pressure and heart rate in different time points during analgesia are shown in Table 3.

Mild hypotension appeared in 2 patients from the EG, but only 1 needed vasopressors.

Table 4 shows the different RS scores in patients from both groups, analysed at different time points after the onset of analgesia. Sedation was significantly higher in the RG at all times during birth, $\mathrm{p}<0.0001 .2$ patients from the RG reached the sedation score 4 according to RSS. Remifentanil was stopped temporarily and after 3 minutes the analgesia proceeded with one step lower doses.

The side effects of both types of analgesia are presented in Table 5. The incidence of nausea was higher in the RG, vomiting was almost the same in both groups, while itching and hyperthermia were more common in the EG.

In this study, the main cause of CTG irregularities was the reduction of variability and early decelerations, however, 4 patients from the RG and 5 patients in the EG experienced serious disorders or pathological CTG records, and in those patients, babies were rapidly delivered. All babies in this study, born with a Caesarean section under a foetal distress, had good Apgar scores and good acid-base status.

Neonatal outcomes are shown in Table 6. Apgar scores of the neonates are almost the same in both groups, there was not a need for use of naloxone or neonatal resuscitation. The median values of all parameters of the umbilical arterial acid-base status of neonates in the current study were within the normal limits. All the parameters we examined were similar in both groups, except the values of base excess, which was significantly lower in the RG.

The mean total consumption of remifentanil during a PCA with remifentanil was $1950 \mu \mathrm{g}$ (450$6400 \mu \mathrm{g})$ over a median period of 165 minutes. The average effective bolus during remifentanil analgesia was $0.33 \mu \mathrm{g} / \mathrm{kgTT}(0.1-1 \mu \mathrm{g} / \mathrm{kgTT})$.

\section{DISCUSSION}

Desaturation is the main side effect during intravenous analgesia with remifentanil. Compared to epidural analgesia, intravenous analgesia with remifentanil is associated with significantly lower values of oxygen saturation. [5-8] The 
Table 1. Patient characteristics, duration of analgesia, average VAS pain scores and average VAS satisfaction scores

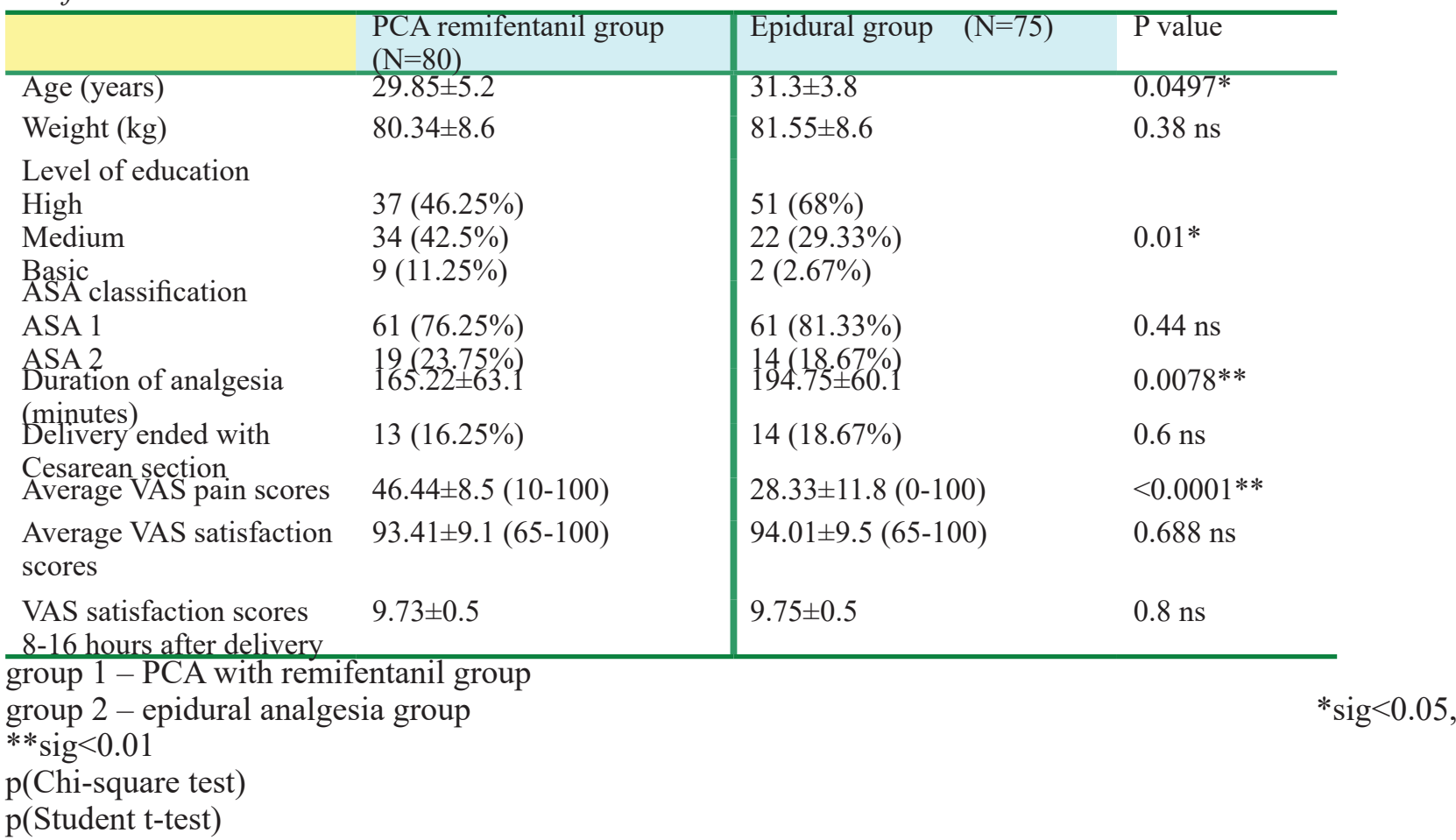

Table 2. Average saturation with oxygen and mean respiratory rate before start and in different time points after the start of analgesia in patients in the remifentanil group and in the epidural group

\begin{tabular}{|c|c|c|c|c|c|c|c|c|}
\hline \multirow[t]{2}{*}{$\mathrm{SaO}_{2}$} & & \multicolumn{3}{|c|}{ Remifentanil group } & \multicolumn{3}{|c|}{ Epidural group } & \multirow[t]{2}{*}{$\mathrm{p}$ value } \\
\hline & & $\mathrm{N}$ & mean $\pm \mathrm{SD}$ & $\min -\max$ & $\mathrm{N}$ & mean $\pm \mathrm{SD}$ & $\min -$ & \\
\hline \multirow{4}{*}{$\begin{array}{l}\text { Before } \\
\text { start } \\
15 \mathrm{~min}\end{array}$} & $\mathrm{SaO}_{2}$ & \multirow[t]{2}{*}{80} & $98.35 \pm 0.9$ & $96-100$ & \multirow[t]{2}{*}{75} & $98.55 \pm 0.8$ & $96-100$ & $0.646 \mathrm{~ns}$ \\
\hline & $\mathrm{RR}^{2}$ & & $22.22 \pm 0.7$ & $21-24$ & & $22.36 \pm 1.5$ & $14-26$ & $0.5 \mathrm{~ns}$ \\
\hline & $\mathrm{SaO}_{2}$ & \multirow[t]{2}{*}{80} & $96.86 \pm 1.5$ & $89-100$ & \multirow[t]{2}{*}{75} & $98.08 \pm 0.9$ & $96-100$ & $<0.0001 * *$ \\
\hline & $\mathrm{RR}^{2}$ & & $19.62 \pm 2.1$ & $7-22$ & & $20.91 \pm 1.6$ & $12-23$ & $0.00006^{* *}$ \\
\hline \multirow[t]{2}{*}{$30 \mathrm{~min}$} & $\mathrm{SaO}_{2}$ & \multirow[t]{2}{*}{79} & $96.78 \pm 1.2$ & $93-100$ & \multirow[t]{2}{*}{75} & $98.12 \pm 0.8$ & $96-100$ & $<0.0001 * *$ \\
\hline & $\mathrm{RR}^{2}$ & & $18.51 \pm 1.6$ & $9-21$ & & $20.71 \pm 1.8$ & $12-24$ & $<0.0001 * *$ \\
\hline \multirow[t]{2}{*}{$60 \mathrm{~min}$} & $\mathrm{SaO}_{2}$ & \multirow[t]{2}{*}{70} & $96.88 \pm 1.4$ & $92-100$ & \multirow[t]{2}{*}{70} & $98.09 \pm 0.8$ & $95-99$ & $<0.0001 * *$ \\
\hline & $\mathrm{RR}^{2}$ & & $18.29 \pm 1.6$ & $10-21$ & & $20.61 \pm 1.8$ & $12-24$ & $<0.0001 * *$ \\
\hline \multirow[t]{2}{*}{$120 \mathrm{~min}$} & $\mathrm{SaO}_{2}$ & \multirow[t]{2}{*}{50} & $96.54 \pm 1.2$ & $95-99$ & \multirow[t]{2}{*}{61} & $98.03 \pm 0.8$ & $97-98$ & $<0.0001 * *$ \\
\hline & $\mathrm{RR}^{2}$ & & $17.59 \pm 1.6$ & $11-20$ & & $20.56 \pm 1.9$ & $11-24$ & $<0.0001 * *$ \\
\hline \multirow[t]{2}{*}{$240 \mathrm{~min}$} & $\mathrm{SaO}_{2}$ & \multirow[t]{2}{*}{9} & $96.57 \pm 0.9$ & $95-98$ & \multirow[t]{2}{*}{12} & $98.3 \pm 0.8$ & $97-99$ & $0.0013 * *$ \\
\hline & $\mathrm{RR}^{2}$ & & $17.1 \pm 2.0$ & $12-19$ & & $21.07 \pm 0.8$ & $20-23$ & $<0.00001^{* *}$ \\
\hline \multirow[t]{2}{*}{ Average } & $\mathrm{SaO}_{2}$ & \multirow[t]{2}{*}{80} & $96.95 \pm 1.4$ & $89-100$ & \multirow[t]{2}{*}{75} & $98.22 \pm 0.6$ & $95-100$ & $<0.0001 * *$ \\
\hline & $\mathrm{RR}^{2}$ & & $18.67 \pm 0.9$ & $7-24$ & & $20.85 \pm 1.4$ & $11-26$ & $<0.0001 * *$ \\
\hline
\end{tabular}

**sig<0.01

$\mathrm{p}$ (Student t-test) 
Table 3. The mean values of blood pressure (systolic and diastolic) and heart rate in different time points during labor analgesia

\begin{tabular}{|c|c|c|c|c|c|c|c|}
\hline \multirow[t]{2}{*}{ BP and $H R$} & \multicolumn{3}{|c|}{ Remifentanil group } & \multicolumn{3}{|c|}{ Epidural group } & \multirow[t]{2}{*}{ p value } \\
\hline & $\mathbf{N}$ & $\begin{array}{l}\text { Mean } \pm \text { SD } \\
\text { SBP }(\mathrm{mmHg}) \\
\text { DBP }(\mathrm{mmHg}) \\
\text { HR beats } / \mathrm{min}\end{array}$ & $\min -\max$ & $\mathbf{N}$ & $\begin{array}{l}\text { mean } \pm \text { SD } \\
\text { DBP }(\mathrm{mmHg}) \\
\text { SBP }(\mathrm{mmHg}) \\
\text { HR beats } / \mathrm{min}\end{array}$ & $\min -\max$ & \\
\hline $\begin{array}{c}\text { Before } \\
\text { beginning }\end{array}$ & 80 & $\begin{array}{l}131.9 \pm 10.9 \\
82.97 \pm 6.7 \\
85.88 \pm 8.1\end{array}$ & $\begin{array}{l}110-160 \\
70-102 \\
68-102\end{array}$ & 75 & $\begin{array}{l}133.45 \pm 10.6 \\
83.43 \pm 6.6 \\
88.06 \pm 7.6\end{array}$ & $\begin{array}{l}110-154 \\
65-99 \\
66-110\end{array}$ & $\begin{array}{l}0.37 \mathrm{~ns} \\
0.67 \mathrm{~ns} \\
0.1 \mathrm{~ns}\end{array}$ \\
\hline $30 \mathrm{~min}$ & 80 & $\begin{array}{l}130.62 \pm 9.8 \\
82.23 \pm 6.6 \\
82.56 \pm 8.8\end{array}$ & $\begin{array}{l}112-160 \\
64-101 \\
60-102\end{array}$ & 75 & $\begin{array}{l}127.43 \pm 10.8 \\
76.55 \pm 6.5 \\
85.75 \pm 7.5\end{array}$ & $\begin{array}{l}107-150 \\
60-94 \\
65-112\end{array}$ & $\begin{array}{l}0.057 \mathrm{~ns} \\
<0.0001 * * \\
0.02 *\end{array}$ \\
\hline $60 \mathrm{~min}$ & 79 & $\begin{array}{l}129.74 \pm 9.6 \\
80.86 \pm 6.6 \\
80.67 \pm 8.5\end{array}$ & $\begin{array}{l}109-155 \\
68-109 \\
62-102\end{array}$ & 75 & $\begin{array}{l}125.16 \pm 9.4 \\
74.32 \pm 6.6 \\
83.97 \pm 6.9\end{array}$ & $\begin{array}{l}104-144 \\
58-87 \\
66-108\end{array}$ & $\begin{array}{l}0.003 * * \\
<0.0001 * * \\
0.012 *\end{array}$ \\
\hline $90 \mathrm{~min}$ & 70 & $\begin{array}{l}130.23 \pm 9.6 \\
79.38 \pm 7.2 \\
79.88 \pm 7.5\end{array}$ & $\begin{array}{l}105-157 \\
51-94 \\
60-97\end{array}$ & 70 & $\begin{array}{l}126.53 \pm 8.6 \\
76.03 \pm 6.1 \\
84.56 \pm 7.6\end{array}$ & $\begin{array}{l}110-152 \\
62-90 \\
62-106\end{array}$ & $\begin{array}{l}0.016^{*} \\
0.003^{* *} \\
0.0004^{* *}\end{array}$ \\
\hline $120 \mathrm{~min}$ & 50 & $\begin{array}{l}131.47 \pm 10.4 \\
80.83 \pm 5.4 \\
79.65 \pm 7.34\end{array}$ & $\begin{array}{l}108-169 \\
69-92 \\
58-94\end{array}$ & 61 & $\begin{array}{l}127.68 \pm 8.3 \\
77.47 \pm 4.9 \\
85.32 \pm 8.1\end{array}$ & $\begin{array}{l}110-148 \\
69-89 \\
58-94\end{array}$ & $\begin{array}{l}0.031 * \\
0.0007 * * \\
0.00013 * *\end{array}$ \\
\hline $240 \mathrm{~min}$ & 9 & $\begin{array}{l}129.67 \pm 7.9 \\
78.89 \pm 4.2 \\
79.55 \pm 8.3\end{array}$ & $\begin{array}{l}119-142 \\
70-84 \\
65-89\end{array}$ & 12 & $\begin{array}{l}132.19 \pm 9.3 \\
81.28 \pm 7.6 \\
84.38 \pm 8.0\end{array}$ & $\begin{array}{l}112-142 \\
65-95 \\
72-102\end{array}$ & $\begin{array}{l}0.5 \mathrm{~ns} \\
0.4 \mathrm{~ns} \\
0.0004 * *\end{array}$ \\
\hline $\begin{array}{l}\text { SBP - systo } \\
\text { DBP - diast } \\
\text { HR - heart } r\end{array}$ & 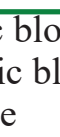 & $\begin{array}{l}\text { pressure } \\
\text { d pressure }\end{array}$ & $\begin{array}{l}*_{\text {sig }}<0 . \\
*_{\text {sig }}<0 \\
\text { p }(\text { Stud }\end{array}$ & & & & \\
\hline
\end{tabular}

Table 4. Ramsey sedation score in different time points after the start of analgesia

\begin{tabular}{lllll|lllll}
\hline RSS & \multicolumn{2}{l|}{ Remifentanil group } & \multicolumn{2}{l}{ Epidural group } \\
& $1 \mathrm{n}(\%)$ & $2 \mathrm{n}(\%)$ & $3 \mathrm{n}(\%)$ & $4 \mathrm{n}(\%)$ & $1 \mathrm{n}(\%)$ & 2 & $\mathrm{n}(\%)$ & $3 \mathrm{n}(\%)$ & $4 \mathrm{n}(\%)$ \\
\hline $15 \mathrm{~min}$ & $75(93.75)$ & $5(6.25)$ & 0 & 0 & $75(100)$ & 0 & 0 & 0 \\
$30 \mathrm{~min}$ & $25(31.25)$ & $54(67.5)$ & $1(1.25)$ & 0 & $75(100)$ & 0 & 0 & 0 \\
$60 \mathrm{~min}$ & $10(12.66)$ & $51(64.56)$ & $18(22.78)$ & 0 & $69(92)$ & $6(8)$ & 0 & 0 \\
$90 \mathrm{~min}$ & $8(11.73)$ & $38(54.29)$ & $24(34.28)$ & 0 & $49(70)$ & $21(30)$ & 0 & 0 \\
$120 \mathrm{~min}$ & $2(3.77)$ & $30(56.60)$ & $20(37.73)$ & $1(1.88)$ & $31(50.82)$ & $30(49.18)$ & 0 & 0 \\
$240 \mathrm{~min}$ & 0 & $4(40)$ & $5(50)$ & $1(10)$ & $10(66.67)$ & $5(33.33)$ & 0 & 0 \\
$300 \mathrm{~min}$ & 0 & 0 & $2(100)$ & 0 & $3(50)$ & $3(50)$ & 0 & 0 \\
\hline
\end{tabular}

Table 5. Side effects during labor analgesia

\begin{tabular}{llll}
\hline & Remifentanil group (80) & Epidural group (75) & P value \\
\hline Nausea & $23(28.75 \%)$ & $14(18,67 \%)$ & $0.14 \mathrm{~ns}$ \\
Vomiting & $3(3.75 \%)$ & $2(2.67 \%)$ & ${ }^{a} 0.86 \mathrm{~ns}$ \\
Itching & $5(6.25 \%)$ & $11(14.67 \%)$ & ${ }^{\mathrm{a}} 0.08 \mathrm{~ns}$ \\
Hyperthermia $\left(\mathrm{T}>37^{\circ}\right)$ & $2(2.5 \%)$ & $9(12 \%)$ & $0.028^{*}$ \\
FHR abnormalities & $12(15 \%)$ & $13(17.33 \%)$ & $0.69 \mathrm{~ns}$ \\
\hline
\end{tabular}

p(Chi-square test)

${ }^{a} \mathrm{p}$ (Fisher exact two-tailed test)

$*$ sig $<0.05$

FHR- fetal heart rate 
Table 6. Neonatal outcomes (Apgar scores in $1^{\text {st }}, 5^{\text {th }}$ and $10^{\text {th }}$ minute, fetal acid base status-UA, use of naloxane and neonatal resuscitation)

\begin{tabular}{|c|c|c|c|c|c|c|c|}
\hline & \multicolumn{3}{|c|}{ Remifentanil group } & \multicolumn{3}{|c|}{ Epidural group } & \\
\hline & $\mathbf{N}$ & mean $\pm \mathrm{SD}$ & $\min -m a x$ & $\mathbf{N}$ & mean $\pm \mathrm{SD}$ & min-max & \\
\hline Apgar score(VD) & 67 & & & 61 & & & \\
\hline $1^{\mathrm{st}}$ minute & & $8.07 \pm 0.8$ & $3-9$ & & $8.08 \pm 0.5$ & $7-9$ & $0.95 \mathrm{~ns}$ \\
\hline $5^{\text {th }}$ minute & & $9.07 \pm 0.7$ & $5-10$ & & $9.06 \pm 0.4$ & $6-10$ & $0.93 \mathrm{~ns}$ \\
\hline $10^{\text {th }} \min$ & & $9.8 \pm 0.4$ & $8-10$ & & $9.9 \pm 0.3$ & $8-10$ & $0.16 \mathrm{~ns}$ \\
\hline Apgar score(SC) & 13 & & & 14 & & & \\
\hline $1^{\text {st }}$ minute & & $7.85 \pm 0.5$ & $7-9$ & & $7.92 \pm 0.5$ & $7-9$ & $0.71 \mathrm{~ns}$ \\
\hline $5^{\text {th }}$ minute & & $8.85 \pm 0.6$ & $8-10$ & & $8.92 \pm 0.5$ & $8-10$ & $0.71 \mathrm{~ns}$ \\
\hline $\begin{array}{l}10^{\text {th }} \text { min } \\
\text { Fetal acid-base } \\
\text { status (UA) }\end{array}$ & 67 & $9.77 \pm 0.4$ & $8-10$ & 61 & $9.61 \pm 0.6$ & $8-10$ & $0.49 \mathrm{~ns}$ \\
\hline $\mathrm{pH}$ & & $7.28 \pm 0.15$ & 7.03-7.32 & & $7.27 \pm 0.09$ & $6.98-7.38$ & $0.75 \mathrm{~ns}$ \\
\hline $\mathrm{pCO}_{2}(\mathrm{mmHg})$ & & $52.38 \pm 11.27$ & $26.4-79$ & & $52.35 \pm 12.49$ & $32.8-87.5$ & $0.99 \mathrm{~ns}$ \\
\hline $\mathrm{pO}_{2}(\mathrm{mmHg})$ & & $18.61 \pm 5.77$ & $10.5-34.4$ & & $17.65 \pm 4.2$ & $10.3-26.3$ & $0.46 \mathrm{~ns}$ \\
\hline $\begin{array}{l}\mathrm{HCO}_{3} \text { act } \\
(\mathrm{mmol} / \mathrm{l})\end{array}$ & & $22.33 \pm 2.13$ & $16.5-26.9$ & & $22.14 \pm 2.48$ & $14.9-27.0$ & $0.64 \mathrm{~ns}$ \\
\hline $\begin{array}{l}\mathrm{HCO}_{3} \text { std } \\
(\mathrm{mmol} / \mathrm{l})\end{array}$ & & $19.07 \pm 1.97$ & $15.1-22.9$ & & $19.12 \pm 2.02$ & $16.5-24.2$ & $0.94 \mathrm{~ns}$ \\
\hline $\mathrm{BE}(\mathrm{mmol} / \mathrm{l})$ & & $-5.28 \pm 2.85$ & $-12.2-$ & & $-3.74 \pm 2.58$ & $-11.4-$ & ${ }^{\mathrm{a}} 0.0017$ \\
\hline Use of naloxane & 80 & 0 & -1.0 & 75 & 0 & -0.9 & \\
\hline $\begin{array}{l}\text { Neonatal } \\
\text { resuscitation }\end{array}$ & 80 & 0 & & 75 & 0 & & \\
\hline $\begin{array}{l}\text { p(Student t-test) } \\
* * \mathrm{p}<0.01 \\
{ }^{\mathrm{a}} \mathrm{p}(\mathrm{Mann}-\text { Whitney } \\
\text { VD - vaginal deli } \\
\text { SC - Cesarean se } \\
\text { UA - umbilical a1 }\end{array}$ & & & & & & & \\
\hline
\end{tabular}

incidence of maternal desaturation under $95 \%$ in remifentanil analgesia was published in $25-75 \%$ of cases. [6-9] The largest number of studies that investigate remifentanil as labour analgesia at delivery show that respiratory depression with desaturation requiring oxygen substitution is short-lived, with no side effects, and as indicated in a study, ventilatory depression is self-limiting because frequent and painful uterine contractions stimulate ventilation. $[7,9,10]$ In the observational study of Messmer et al from 2016 on 61 patients receiving remifentanil for pain relief, the authors show that the patients using PCA with remifentanil often desaturate, on average once in every 50 minutes, with a mean duration of 16 seconds and that $70 \%$ of the patients desaturated at least once during PCA with remifentanil. [11] But although desaturation is much more common in patients who receive analgesia with remifentanil, several studies have also described desaturation in patients with epidural analgesia. $[5,8,10]$ It is known that episodes of desaturation occur during normal delivery. Some studies have shown a decrease in sat- uration and below 90\% during childbirth, and this is getting worse with receiving opioids. [12, 13]

In recent years many studies have discussed the respiratory side effects associated with remifentanil analgesia. Stocki et al analysing ETCO2, report 27 cases of apnoea in 9 patients during PCA with remifentanil. [6] What is interesting in these cases is that in only 6 cases of apnoea, $\mathrm{SpO} 2$ dropped below 94\%. Another recent study of Weiniger et al from 2017 also emphasizes the moment that monitoring only of SpO2 can overlook the apnoea. [14] Using RR and ETCO2 they counted 62 apnoeas in 10 of 19 patients using remifentanil for labour analgesia. New studies can generate fear and resistance to analgesia with remifentanil, but if we followed the recommendations and protocols, we should not be scared.

The existence of a link between the dose of remifentanil and the occurrence of desaturation is very often analysed in different studies. In their studies, Stocki and Messmer concluded that in parturients with an increase in the bolus doses 
of remifentanil there is no increase in the risk of desaturation. [6, 11] However, the risk of desaturation can be increased by the use of higher doses of remifentanil over $0.75 \mu \mathrm{g} / \mathrm{kg}$, somewhere above $1.05 \mu \mathrm{g} / \mathrm{kg}$. $[7,15]$ Desaturation may occur at low doses of remifentanil, even at doses of 0.2 $\mu \mathrm{g} / \mathrm{kg} 10$, possibly due to individual variations in opioid sensitivity. [7] [16] This demonstrates that it is impossible to determine an effective and safe dose that will be suitable for all parturients, so it is always the best to start with smaller doses $0.15 \mu \mathrm{g} / \mathrm{kg}$ or $0.2 \mu \mathrm{g} / \mathrm{kg}$, then gradually titrating and rising according to individual needs. $[10,15]$ Aspiring to a safer PCA with remifentanil, Leong et al designed an interactive feedback system for continuous monitoring of side effects, for greater safety and better titration of doses. [17] The authors work on the improvement of the system so that it can respond to the reduction of respiratory frequency or connect it with a capnograph or with a cardiotocograph. [18]

Respiratory depression is defined as a reduced respiratory rate, less than 8-9 respirations per minute and is a common side effect of remifentanil analgesia. [5] [6] In newer studies special attention is paid to respiratory frequency as an early warning sign for apnoea, along with capnography at times when monitoring of $\mathrm{SpO} 2$ can overlook the apnoea. [14] In our study, which noted the respiratory rate every 15 minutes, a significantly lower number of respirations was observed in the $\mathrm{RG}$ compared to the EG at all time points during labour. A large systematic review of Cochrane of 2017, comparing all available papers with regard to respiratory depression, did not find a difference between remifentanil and epidural analgesia, with a graded 'low' quality of evidence. [19]

There are several case reports of very serious complications in obstetric patients, started as remifentanil labour analgesia, 2 patients with respiratory arrest and 1 patient with cardiac arrest. [20-22] What is to be noted is that all of the cases were with the simultaneous use of multiple methods of analgesia and without a continuous presence of an anaesthesiologist or nurse during analgesia. Everything ended well, but these cases suggest further required caution, continuous respiratory monitoring, preparation at all times and respect for specific recommendations and protocols for obstetric patients during remifentanil labour analgesia. All recommendations and protocols were respected in the study.
Sedation also appears as a frequent side effect of remifentanil analgesia. Different levels of maternal sedation are common, while in some studies an incidence of sedation is observed of nearly $100 \%$. [7, 9, 11, 15, 23] In our study there was a significantly higher level of sedation in RG than in EG, which was expected, with correlation to other studies. [6-8]

Several studies have shown that remifentanil in doses used for labour analgesia is haemodynamically inert, but compared to epidural analgesia reduces the risk of hypotension. $[5,9$, $15,19,23-25]$ On the other hand, a significantly lower pulse was measured in patients in the RG. In multiple studies that compare heart rate between remifentanil and epidural analgesia, bradycardia associated with any type of analgesia has not been found. [9, 23] Although we do not have many cases of haemodynamic instability, the literature has described the case of a cardiac arrest in a patient during analgesia with remifentanil. [22] Continuous measurement of the heart rate is obligatory in patients receiving remifentanil for labour analgesia.

It is already known that nausea and vomiting occur during birth even when there is no analgesia and it is difficult to determine the incidence directly associated with opioids. The fact that in this study nausea is higher in the RG is probably the result of significantly higher pain scores in this group, which supports the view that pain has at least a partial role in the mechanisms of nausea and vomiting associated with labour. [26]

Loss of variability is a typical finding of opioid analgesia during labour, both in intravenous and epidural analgesia, and is due to the direct effect of the opioid on the central nervous system of the foetus.[27] Severe bradycardia in neonates and children has been reported in several cases of paediatric anaesthesia in the use of remifentanil in intensive care or as part of general anaesthesia.[28] Many studies describe the changes in the CTG record during remifentanil analgesia and all of them describe the changes as short-lived and without the need for obstetric intervention. [7, 9, 23] Compared to other methods of anaesthesia, in the large systemic review of Cochrane from 2017, analgesia with remifentanil has a lower risk of CTG irregularities compared to another opioid, and quite the same compared to epidural analgesia. [19] 
Several studies examined the acid-base status of the newborn after analgesia with remifentanil, and most of them agree that remifentanil analgesia is completely safe for the newborn, which is probably the result of a rapid metabolism or redistribution of remifentanil. $[6,10]$ In terms of epidural analgesia, it is associated with the same or better $\mathrm{pH}$ and BE. $[6,7,19]$ Although a major retrospective study of Lin and collaborators from 2014, showed a lower $\mathrm{pH}$ and a significantly lower BE in patients with analgesia with remifentanil and suggests that despite the rapid and easy metabolism of remifentanil in the newborn, it still has an effect on the newborn and the resuscitation kit should be at hand at all times. [29]

In our study, as well in all available studies, the Apgar scores of the neonates were in normal range after administration of remifentanil. $[5,6][7,19]$

The difference in analgesic efficacy between PCA with remifentanil and epidural analgesia at all times during labour was visible and statistically significant. On the other hand, the satisfaction scores of the patients in this study were almost the same in both groups at all times, with no statistically significant difference. Many studies investigated the satisfaction of the patients and in all of them, patients are satisfied with analgesia with remifentanil, although compared with epidural analgesia, the results are different. A number of studies did not find a significant difference in maternal satisfaction, while some studies show us greater satisfaction in the epidural group compared to PCA with remifentanil. [5, 6, 8, 10, 19, 23, $24,30]$

\section{CONCLUSION}

Patient-controlled intravenous analgesia with remifentanil provides minimal side effects of the mother and the newborn with a satisfactory level of analgesia and high patient satisfaction. It can be a great alternative to epidural analgesia, but continuous respiratory monitoring and use of all consensus recommendations for maternal and foetal safety are mandatory.

\section{REFERENCES}

1. Wong CA. Advances in labor analgesia-review. International Journal of Women's Health 2009; 1: 139-54.

2. Wong CA. Epidural and Spinal Analgesia/Anesthesia for Labor and Vaginal Delivery, em: Chestnut DH et al. - Obstetric Anesthesia: Principles and Practice, $4^{\mathrm{a}}$ Ed, Philadelphia, Mosby Elsevier 2009; 429-92.

3. Egan TD. Pharmacokinetics and pharmacodynamics of remifentanil: an update in the year 2000. Curr Opin Anaesthesiol 2000; 13: 449-55.

4. Kan RE, Hughes SC, Rosen MA, Kessin C, Preston PG, Lobo EP. Intravenous remifentanil: placental transfer, maternal and neonatal effects. Anesthesiology 1998; 88: 1467-74.

5. Freeman LM, Bloemenkamp KW, Fransen MT, Papatsonis DN, Hajenius PJ, Hollman MW et al. Patient controlled analgesia with remifentanil versus epidural analgesia in labour: randomised multicentre equivalence trial. BMJ 2015; 350: h846.

6. Stocki D, Matot I, Elnav S. A randomized controlled trial of the efficacy and respiratory effects of patient-controlled intravenous remifentanil analgesia and patient-controlled epidural analgesia in laboring women. Anesth Analg 2014; 118: 589-97.

7. Tveit TO, Seiler S, Halvorsen A, Rosland JH. Labour analgesia: a randomised, controlled trial comparing intravenous remifentanil and epidural analgesia with ropivacaine and fentanyl. Eur J Anaesthesiol. 2012; 29: 129-36.

8. Douma MR, Stienstra R, Middeldorp JM, Arbous MS, Dahan A. Differences in maternal temperature during labour with remifentanil patient-controlled analgesia or epidural analgesia: a randomised controlled trial. Int J Obstet Anesth. 2015; 24: 313-22.

9. Blair JM, Hill DA, Fee JP. Patient-controlled analgesia for labour using remifentanil: a feasibility study. Br J Anaesth 2001; 87: 415-20.

10. Volmanen P, Sarvela J, Akural EI, Raudaskoski $\mathrm{T}$, Korttila K, Alahuhta S. Intravenous remifentanil vs. epidural levobupivacaine with fentanyl for pain relief in early labour: a randomised, controlled, double-blinded study. Acta Anaesthesiologica Scandinavica 2008; 52: 249-55.

11. Messmer A; Potts M; Orlikowski E. A prospective observational study of maternal oxygenation during remifentanil patient-controlled analgesia use in labour. Anesthesia 2016; 71: 171-6. 
12. Griffin RP, Reynolds F. Maternal hypoxaemia during labour and delivery: the influence of analgesia and effect on neonatal outcome. Anaesthesia 1995; 50: 151-6.

13. Minnich ME, Brown M, Clark RB, Miller FC, Thompson DS. Oxygen desaturation in women in labor. Journal of Reproductive Medicine 1990; 35: 693-6.

14. Weiniger, Carvalho, Stocki, Einav. Analysis of Physiological Respiratory Variable Alarm Alerts Among Laboring Women Receiving Remifentanil. Anesthesia \& Analgesia April 2017; 124: 1211-18.

15. Tveit TO, Halvorsen A, Seiler S, Rosland JH. Efficacy and side effects of intravenous remifentanil patient-controlled analgesia used in a stepwise approach for labour: an observational study. Int $\mathrm{J}$ Obstet Anesth. 2013; 22: 19-25.

16. Landau R, Cahana A, Smiley RM, Antonarakis ES, Blouin JL. Genetic Variability of $\mu$-Opioid Receptor in an Obstetric Population. Anesthesiology 4 2004; 100: 1030-3.

17. Leong WL, Sng BL, Zhang Q, Han NLR, Sultana R, Sia ATH. A case series of vital signs-controlled, patient assisted intravenous analgesia (VPIA) using remifentanil for labor and delivery. Anesthesia 2017; 72: 845-52.

18. C. F. Weiniger, B. Carvalho,R. Landau-Cahana. Optimising triggers for patient-assisted remifentanil analgesia during labour. Anesthesia 2017; 72: $1155-6$.

19. Weibel S, Jelting Y, Afshari A, Pace N, Eberhart LHJ, Jokinen J et al. Patient-controlled analgesia with remifentanil versus alternative parenteral methods for pain management in labour. Cochrane Database of Systematic Reviews 2017, Issue 4. Art. No.: CD011989.

20. J.C Bonner, W. McClymont Respiratory arrest in an obstetric patient using remifentanil patient-controlled analgesia-case report. Anaesthesia 2012; 67: 538-40.
21. C.Pruefer, A.Bewlay. Respiratory arrest with remifentanil patient-controlled analgesia - another case. Anaesthesia 2012; 67: 1044-5.

22. Marr R, Hyams J, Bythell V. Cardiac arrest in an obstetric patient using remifentanil patient- conrolled analgesia. Anaesthesia 2013; 68: 283-7.

23. Stourac P, Suchomelova H, Stodulkova M, Huser M, Krikava I, Janku P et al. Comparasion of parturient-controlled remifentanil with epidural bupivacaine and sufentanil for labor analgesia, randomized controlled trial. Biomed Pap Med Fac Univ Palacky Olom Czech Rep 2014; 158: 227-32.

24. El-Kerdawy H, Farouk A. Labor analgesia in preeclampsia: remifentanil patient controlled intravenous analgesia versus epidural analgesia. Middle East Journal of Anesthesiology 2010; 20: 539-45.

25. D’Onofrio P, Novelli AMM, Mecacci F; Scarselli G. The Efficacy and Safety of Continuous Intravenous Administration of Remifentanil for Birth Pain Relief: An Open Study of 205 Parturients. Anesthesia \& Analgesia 2009; 109: 1922-4.

26. Andersen R, Krohg K. Pain as a major cause of postoperative nausea. Can Anaesth Soc J 1976; 23: 366-9.

27. Leighton BL,Halpern SH. The effects of epidural analgesia on labor, maternal and neonatal outcomes:a systematic review. Am J Obstet Gynecol 2002; 186: 69-77.

28. Marsh DF, Hodkinson B. Remifentanil in paediatric anaesthetic practice. Anaesthesia 2009; 64: 301-8.

29. Lin $\mathrm{R}$, Tao $\mathrm{Y}, \mathrm{Yu} \mathrm{Y,} \mathrm{Xu} \mathrm{Z,} \mathrm{Su} \mathrm{J.} \mathrm{Intravenous}$ remifentanil versus epidural ropivacaine with sufentanil for labour analgesia: A retrospective study. Plos One 2014; 9(11): e112283.

30. Logtenberg SLM, Oude Rengerink K, Verhoeven CJ, Freeman LM, van den Akker E, Godfried MB et al. Labour pain with remifentanil patient-controlled analgesia versus epidural analgesia: a randomised equivalence trial. BJOG 2017; 124 : 652-60. 


\title{
Резиме
}

\section{НЕСАКАНИ ЕФЕКТИ ОД ИНТРАВЕНСКА АНАЛГЕЗИЈА СО РЕМИФЕНТАНИЛ КОНТРОЛИРАНА ОД ПАЦИЕНТ СПОРЕДЕНО СО ИНТЕРМИТЕНТНАТА ЕПИДУРАЛНА АНАЛГЕЗИЈА ПРИ ПОРОДУВАЊЕ - РАНДОМИЗИРАНО КОНТРОЛИРАНО ИСПИТУВАҢЕ}

\author{
Дафина Караџова ${ }^{1}$, Мирјана Шошолчева ${ }^{2}$, Емилија Иванов ${ }^{1}$, Атанас Сивевски $^{1}$, \\ Иво Каев ${ }^{1}$, Адријан Карталов ${ }^{3}$, Билјана Кузмановска ${ }^{3}$, Роза Спасова ${ }^{1}$, \\ Горан Кочовски ${ }^{1}$, Ирена Алексиовска-Папестиев ${ }^{1}$ \\ 1 Универзитетска клиника за гинекологија и акушерство, Скопје, Северна Макеоднија \\ 2 Универзитетска клиника за хируршки болести „Св. Наум Охридски“, Скопје, Северна Македонија; \\ 3 Универзитетска клиника за ТОАРИЛУЦ, Скопје, Северна Македонија
}

Вовед: Епидуралната аналгезија е златен стандард во акушерската анестезија и аналгезија. Но, во состојби кога е таа контраиндицирана, несакана од пациентот или, едноставно, недостапна, ремифентанилот може да биде одлична алтернатива. Целта на оваа студија е да ги анализира несаканите ефекти на интравенозно даден ремифентанил на пумпа за пациент контролирана аналгезија (ПКА), споредени со епидуралната аналгезија при породување.

Материјал и методи: 155 бремени жени во термин беа вклучени во студијата и поделени во две групи: ремифентанил група (РГ) и епидурална група (ЕГ). Пациентките од РГ добија интравенски ремифентанил на пумпа за ПКА, додека пациентките од ЕГ добија епидурална аналгезија со програмирано интермитентно болус дозирање. Наша примарна цел беше мајчината безбедност, секундарна цел беше неонаталната безбедност.

Резултати: Резултатите ни покажуваат значително помали вредности на $\mathrm{SaO} 2$ кај родилките од РГ $(96,95 \pm 1,4$ vs 98,22 $\pm 0,6)$ и значително повисока респираторна фреквенција во ЕГ во сите временски точки после почеток на аналгезијата $(20,85 \pm 1,4$ vs $18.67 \pm 0,9)$. Седацијата, гадењето и повраќањето беше почесто кај РГ, додека во ЕГ почеста беше покачената температура, чешањето и неправилности во кардиотокографскиот запис. Во однос на новородените, не се најде значајна разлика меѓу двете групи во однос на Апгар-скоровите, рН, pСО2, pО2 и бикарбонатите, додека базниот ексцес беше значително понизок во РГ.

Заклучок: ПКА со ремифентанил е безбедна за мајката, фетусот и новороденчето, со минимални несакани ефекти. Континуиран респираторен мониторинг, достапност на кислород и следење на консензус препораки се задолжителни.

Клучни зборови: ремифентанил, епидурална анлгезија, несакани ефекти 